1. J. P. Naylor and P. R. Krahe: Met. Trans., 1974, vol. 5, pp. 1699-701.

2. M. J. Roberts: Met. Trans., 1970, vol. 1, pp. 3287-94.

3. S. Matsuda, T. Inoue, H. Mimura, and Y. Okamura: Trans. ISIJ, 1972, vol. 12 pp. 325-33.

4. H. Ohtani, F. Terasaki, and T. Kunitake: ibid., pp. 118-27.

5. D. Guttmann-Senicourt and P. R. Krahe: Mem. Sci. Rev. Met., 1973, LXX, no. 7-8, pp. 559-67.
6. C. A. Apple, R. N. Caron, and G. Krauss: Met. Trans., 1974, vol. 5, pp. 593.99.

7. J. M. Chilton, C. J. Barton, and G. R. Speich: J. Iron Steel Inst., 1963, vol. 196, pp. 518-31.

8. K. J. Irvine and F. B. Pickering: J. Iron Steel Inst., 1957, vol. 187, pp. 292-309.

9. U. H. Lindborg and B. L. Averbach: Acta Met., 1966, vol. 14, p. 1583.

10. G. R. Speich and P. R. Swann: J. Iron Steel Inst., 1965, vol. 203, pp. 480-85.

Correction to Met. Trans., 1974, vol. 5

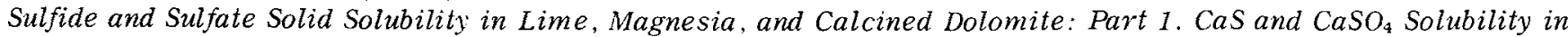
CaO, by E. T. Turkdogan, B. B. Rice, and J. V. Vinters, pp. 1527-35.

\title{
Page 1535
}

The values of $p_{\mathrm{CO}_{2}} / p_{\mathrm{CO}}$ for $\mathrm{CaO}-\mathrm{CaS}$ equilibrium in Fig. 15 of this paper correspond to $\left(p_{\mathrm{CO}} / p_{\mathrm{CO}}\right)^{3}$. The authors regret this unfortunate error in the paper. The following diagram, Fig. 15 $(a)$, is the correct form:

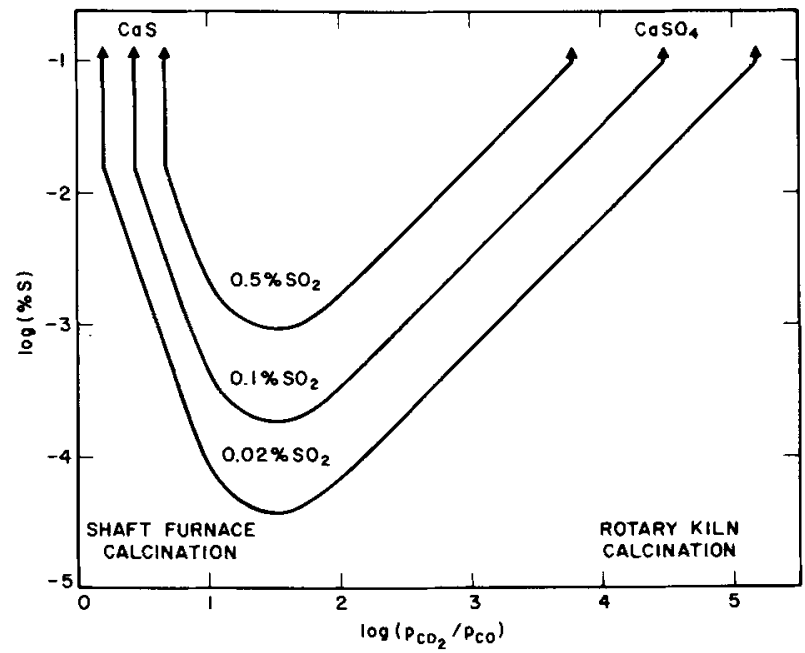

Fig. $15(a)$-Sulfide and sulfate solubility in lime at $1200^{\circ} \mathrm{C}$ as a function of gas composition in relation to average gas composition in shaft furnace and rotary kiln calcination. 